\title{
THE EFFECTS OF CAPITAL STRUCTURE AND GOOD CORPORATE GOVERNANCE ON DIVIDEND POLICY AND FIRM VALUE An Empirical Research at Banks Listed in Indonesia Stock Exchange for the Period of 2008-2012
}

\author{
${ }^{1)}$ Raras Puspa Dewi, ${ }^{2)}$ Suhadak, ${ }^{3)}$ Siti Ragil Handayani \\ ${ }^{123)}$ Fakultas Ilmu Administrasi Universitas Brawijaya \\ Email :raras.pokromo@gmail.com
}

\begin{abstract}
ABSTRAK
Penelitian ini menguji hubungan kausal antara Struktur Modal dan Good Corporate Governance pada Kebijakan Dividen dan Nilai Perusahaan di bank yang terdaftar di Bursa Efek Indonesia (BEI) untuk periode 2008-2012 menggunakan PLS (Jalur Least Square) analisis. Data dikumpulkan dari laporan keuangan 7 perbankan tahunan yang go public di Bursa Efek Indonesia 2008-2012 yang terpilih sebagai sampel dalam periode pengamatan 5 tahun dengan menggunakan purposive sampling. Ditemukan bahwa Struktur Modal memiliki Kebijakan berpengaruh signifikan Dividen positif, Good Corporate Governance berpengaruh tidak signifikan negatif pada Kebijakan Dividen, Kebijakan Dividen memiliki efek non-signifikan positif terhadap Nilai Perusahaan, Struktur Modal berpengaruh signifikan positif terhadap Nilai Perusahaan, dan juga Good Corporate Governance berpengaruh signifikan positif terhadap Nilai Perusahaan. Hasil ini akan memberikan saran yang baik untuk perusahaan untuk setiap keputusan manajemen. Penelitian ini bertujuan untuk memberikan kontribusi untuk penelitian manajemen keuangan pembangunan khususnya terkait topik akuntansi keuangan dan keputusan manajemen.
\end{abstract}

Kata kunci: Struktur Modal, Good Corporate Governance, Kebijakan Dividen, Nilai Perusahaan, Bank, Bursa Efek Indonesia (BEI)

\begin{abstract}
This study examined the causal relationship between Capital Structure and Good Corporate Governance on Dividend Policy and Firm Value at banks listed in Indonesia Stock Exchange (IDX) for the Period 2008-2012 using PLS (Path Least Square) analysis. Data were collected from 7 annual banking financial statements that go public in Indonesia Stock Exchange from 2008 to 2012 that chosen as samples in 5 years observation period using purposive sampling. It was found that Capital Structure has positive significant effect Dividend Policy, Good Corporate Governance has negative non-significant effect on Dividend Policy, Dividend Policy has positive non-significant effect on Firm Value, Capital Structure has positive significant effect on Firm Value, and also Good Corporate Governance has positive significant effect on Firm Value. These results will provide a good suggestion to companies for any management decision. This study seeks to contribute to the development financial management research especially related topic on financial accounting and management decision.
\end{abstract}

Keywords: Capital Structure, Good Corporate Governance, Dividend Policy, Firm Value, Banks, Indonesia Stock Exchange (IDX) 


\section{INTRODUCTION}

\section{Background}

Globalization encourages the emergence of competition to be getting tougher. Therefore, firms are constantly working to improve performance that reflected in the value of firm. Value is significant for firm because the firm's main goal is to increase the value of firm itself. High value of firm is the desire of every owner of firm because of high value indicates the overall prosperity of the shareholders. In an environment of global competition that occurs at this time in many developing countries firms, one of which is Indonesia, expected to show better performance. It is intended to enable firms achieve the maximum value of firm and gain competitive advantage over its competitor. Competitiveness by getting strategic and successful exploit its competitive advantage, a firm is able to achieve its main goal to get profits above the average and can increase the value of firm at its maximum point.

The long-term goal of firm is to optimize the value of firm. The higher value of firm describes the prosperous owner of firm. Value of firm can describe the state of firm. With good value of firm, the firm will be looked upon favorably by potential investors. Every business owner will always demonstrate to potential investors that they are the right firm as an investment alternative. The company's objectives can be achieved through the implementation of financial management functions carefully and precisely, given any financial decisions taken will affect the other financial decisions that affect firm value (Jensen and Smith, 1994; Fama and French, 1998). Financial management involves the completion of an important decision taken by the company, including investment decisions, financing, and dividend policy. An optimal combination of the three will maximize the value of the company, thus decisions are interrelated to each other (Mbodja and Mukherjee, 1994, and Qureshi, 2006).

Banking industry is a minority industry companies listed in Indonesia Stock Exchange (IDX). Inadequate number of companies banking industry in this current economics conditions have created a competition among companies. This competition makes every company trying to improve performance to achieve goals such high profits. Condition of tough competition is feared will further erode the number of firms in banking industry. An effort to anticipate these conditions, the company's financial managers must be careful in determining the capital structure of the company. With the careful planning in determining the capital structure, the company is expected to enhance shareholder value and is superior to face competition. One of the company's efforts to improve and maintain the performance of the company's capital structure is to measure the ability in influencing the level of company profitability. Capital structure theory explains that capital structure is an important issue for firms, because as good to poor capital structure will have direct effects on the financial position of the firm, which in turn will affect the value of the firm.

The shareholders are the owners of a limited liability firm, and they buy shares because they want to get a financial return. In most cases, shareholders will elect directors, who then will appoint managers to run the company on a daily basis. The manager works on behalf of the shareholders, they should comply with the policies that can enhance shareholder value (Brigham and Houston, 2006). Therefore, the normative goal of financial management is to increase the value of firm, as reflected in its share price (Walker, 2000 and Qureshi and Azid, 2006). The firm's goal that can be achieved through the implementation of the financial management functions carefully and precisely, any financial decisions taken will give effect to the other financial decisions that affect the value of firms.

The existence of information asymmetry between managers and shareholders, move by the connection with the separation between owners and managers. This condition is the basis for the establishment of other explanations why dividend policy to be a thorny issue. This argument is based on the assumption that managers may behave opportunistic indicated with activities that only serve the interests of their own which is not always beneficial to the shareholders (Jensen, 1976). Managerial opportunism hypothesis as expressed by (Jensen, 1986; Jiraporn and Ning, 2006) states that managers have tended to hold cash in the company, which provides them to consume more extra income, to use in building the kingdom, and to invest in projects with revenues only increase their personal prestige but does not benefit shareholders. 
The design of an effective corporate oversight mechanisms to make managers act in the best interests of the shareholders has been a major concern in the area of corporate governance and finance (Allen and Gale, 2001), and continuing research on agency theory is an attempt to design a framework appropriate work to control it . Corporate governance is a control mechanism to regulate and manage the company with a view to increasing prosperity and corporate accountability, which ultimately aim to create shareholder value (Monk and Minow, 2004). Corporate governance is a concept that is based on agency theory, is expected to serve as a tool to provide confidence to investors that they would receive a return on the funds they have invested. Corporate governance is concerned with how the investors believe that managers will benefit them, confident that the manager will not darken or to invest in projects that do not benefit associated with the funds that have been invested by the investor. Corporate governance is also related to how investors control managers (Shleifer and Vishny, 1996).

A dividend policy in firms is a complex thing because it involves the interests of many stakeholders. Shareholders' investment objective is to increase shareholder wealth by acquiring the return of the funds invested. While for the management of the firm is more oriented to increase firm value. Creditors need information about the dividend policy to assess and analyze the possibility of return that would be obtained if it is lending to a firm. Dividend policy is essentially a determination of the portion of the profits will be given to shareholders. Dividend payout policy decisions is important regarding whether cash flow will be paid to investors or will be retained for reinvested by the firm. The amount of the dividend depends on the dividend policy of each firm. The proportion of net profit after tax is distributed as dividends are usually presented in Dividend Payout Ratio (DPR). If dividend paid is well and then the stock price tends to be high, so that the value of the firm is also high. Conversely, if the dividend paid is small then the firm's share price is also low. Ability to pay dividends is closely related to the ability of firms makes a profit. If the firm makes a large profit, the ability to pay dividends is also great. Therefore, with great dividends will increase the value of the firm.
Indonesian public firm have a different composition of the ownership structure of European or American firm that have spread ownership structure (dispersed ownership) so the agency conflict is occurred between managers and shareholders, while Indonesia's ownership structure is highly concentrated so that its agency conflict is occurred between the majority shareholders and minority shareholders. The advantage of its concentrated structure is it has strong leadership and a cohesive management team that was formed by the owners of the family (family-owned) or control members. However, there are problems that firms dominated by a single family tend to be entitles the firm governance to its own interests and sacrificed the minority shareholders. From the existing literature, there is a discovery who indicates that the dominant structure of shareholder plays an active or effective role in corporate governance. As an example in Germany, Mayer (1996) discovered that the large shareholders associated with a bigger director turnover. Similarly with Kaplan (1998) discovered that Japanese's firm with a bigger shareholders more possibly replace their manager because of the worse firm performance.

This research has five objectives: examine the effect of capital structure on dividend policy, the effect of Good Corporate Governance on dividend policy, the effect of dividend policy on firm value, the effect of capital structure on firm value, and examine the effect of Good Corporate Governance on firm value in banking sector firm that listed at Indonesia Stock Exchange (IDX) in 2008-2012. Capital structure is measured using Debt Ratio and Debt to Equity Ratio. Good Corporate Governance is measured using managerial ownership and institutional ownership. Dividend policy is proxied by Dividend Payout Ratio and Dividend Yield. While the firm value is proxied by Return on Investment, Return on Equity, and Price to Book Value which is the ratio between share market value of a firm and replacement value of firm assets.

\section{Research Questions}

1) Does the capital structure have effect on dividend policy?

2) Does the Good Corporate Governance have effect on dividend policy?

3) Does the dividend policy have effect on firm value? 
4) Does the capital structure have effect on firm value?

5) Does the Good Corporate Governance have effect on firm value?

\section{Research Objectives}

1) Analyzing and describing the effect of capital structure on dividend policy.

2) Analyzing and describing the effect of Good Corporate Governance on dividend policy.

3) Analyzing and describing the effect of dividend policy on firm value.

4) Analyzing and describing the effect of capital structure on firm value.

5) Analyzing and describing the effect of Good Corporate Governance on firm value.

\section{THEORETICAL BACKGROUND AND HYPOTESIS}

\section{Capital Structure}

Modern capital structure theory began in 1958, when Professor Franco Modigliani and Merton Miller (here after MM) published what has been called the most influential finance article ever written. Based on a set of assumptions that severely limit, MM prove that value of a firm is unaffected by capital structure. In other words, the results of MM stated that no matter how the company finances its operations, capital structure is irrelevant.

Managers should choose the capital structure that maximizes shareholders wealth. The approach is to consider a trial capital structure, based on the market values of the debt and equity, and then estimate the wealth of the shareholders under this capital structure. This approach is repeated until an optimal capital structure is identified. Brigham and Daves (2007) explained that "The optimal capital structure is the one that strikes the optimal balance between risk and return and thereby maximizes the firm's stock price". Furthermore Brigham and Ehrhardt (2005: 564) mention that there are five steps for the analysis of each potential capital structure: estimate the interest rate the firm will pay; estimate the cost of equity; estimate the weighted average cost of capital; estimate the free cash flows and their present value, which is the value of the firm; deduct the value of the debt to find the shareholders wealth, which want to maximize.

\section{Good Corporate Governance}

Good Corporate Governance is a structure that by stakeholders, shareholders, commissioners, and managers formulate company goals and a means to achieve these goals and monitoring the performance (OECD, 2003). A similar sentiment was expressed by Calburry Committee (2003) "a set of rules that define a relationship between shareholders, manager, creditor the government, employees and other internal and external stakeholder in respect to their and responsibility". Further, corporate governance is a term that comes from the interaction between management, shareholders, and the board of directors and other related parties, due to inconsistencies between the "what" and "what should be", so the emerging corporate governance issues (Tricker, 2003).

In Indonesia as in all countries corporate governance issues are most immediately relevant for three types of firms: those on the stock exchanges and hence with minority, outside shareholders; large private corporations, especially those part of a business group, whose failure or difficulties could have a major impact, especially on its creditor banks; and state-owned enterprises. Each is subject to moral hazard, broadly defined not only to include excessive risk-taking, but looting and other terms of mismanagement (as described in some detail in Simanjuntak 2001), and unwarranted forms and degrees of government interference. For emerging market countries, improving corporate governance can serve a number of important public policy objectives. Good Corporate Governance reduces emerging market vulnerability to financial crises, reinforces property rights, reduces transaction costs and the cost of capital, and leads to capital market development.

\section{Agency Theory}

Company is a mechanism that provides the opportunity for variety of participants to contribute in capital (principal), skills and labor (agent) in order to maximize profits in the long term. While Jensen and Meckling (1976) define an agency relationship as a contract in which one or more (principals) hire another person (the agent) to do some service for their interest by delegating some decision-making authority to the agent. Agency relationship is the basis of the perspective used to understand corporate governance. Agency theory is a theory used to 
explain the relationship between the agent and the principal that constructed in order corporate objectives can be achieved in the maximum level. What is meant which principal is owner of the company and called the agent is the manager of the company. The owner of company has the objective to maximize corporate prosperity.

Agency theory assumes that individuals are motivated by self-interest so that can lead to conflict between the principal and agent. The principals have an interest to increase the prosperity of the company by entering into a contract with an agent, while the agent is likely to be opportunists trying to meet the needs of the economy and psychology. Agency theory, can explain how the parties involved in the company will behaved, because basically between the agent and the principal have different interests that lead to agency conflicts (agent conflict).

\section{Dividend Policy}

Horne and Wachowicz (2003: 270) states that dividend policy is an integral part in corporate financing decisions. Therefore, the main aspect of the company's dividend policy is to determine the proper allocation of profits between dividend payments with the addition of retained earnings of company. However, it is also important other issues relating to the dividend policy of company as a whole either legal problems, liquidity and control, stability of dividends, stock dividends and stock splits, share repurchases as well as various administrative considerations.

Dividend policy is closely related to the dividend payout ratio. The term of dividend payout ratio is the annual cash dividend divided by annual earnings, or dividends per share divided by earnings per share. The ratio indicates the percentage of earnings paid to shareholders in cash. Dividend policy is an integral part in corporate funding decisions. Dividend policy is the decision about how much current profit as a dividend to be paid in lieu of the investment and how much is retained for reinvestment within the company (Brigham and Houston, 2006: 32).

Dividend payout ratio determines the amount of profit that can be retained in the

company as a source of funding. If the company chooses to distribute profit as dividends, it will reduce the profits to be retained and further reduce internal funding resources. Conversely, if the company chooses to hold the profits, the ability of internal funds formation will be even greater. So, the main aspect of the company's dividend policy is to determine the proper allocation of profits between dividend payments by the addition of retained earnings of the company. However is also important the other issues related to overall company dividend policy: legal issues, liquidity and control, stability of dividends (dividends, stock splits, and share repurchases), as well as various administrative considerations.

\section{Firm Value}

The company's main objective is to maximize wealth or firm value. Maximize the value of the company is very important for a company, because by maximizing the value of the company means also maximizing shareholder wealth which is the main goal of the company. Firm value of the firm is the price which willing to paid by prospective buyers if the company is sold. Whereas according to Keown et al. (2004) of the firm is market value of securities of debt and outstanding equity.

\section{CONCEPTUAL FRAMEWORK RESEARCH HYPOTHESIS}

Figure 1 shows conceptual model of this research. There are 5 hypotheses:

H1: Capital Structure has significant effect on Dividend Policy.

H2: Good Corporate has significant effect on Dividend Policy.

H3: Dividend Policy has significant effect on Firm Value.

H4: Capital Structure has significant effect on Firm Value.

H5: Good Corporate Governance has significant effect on Firm Value. 


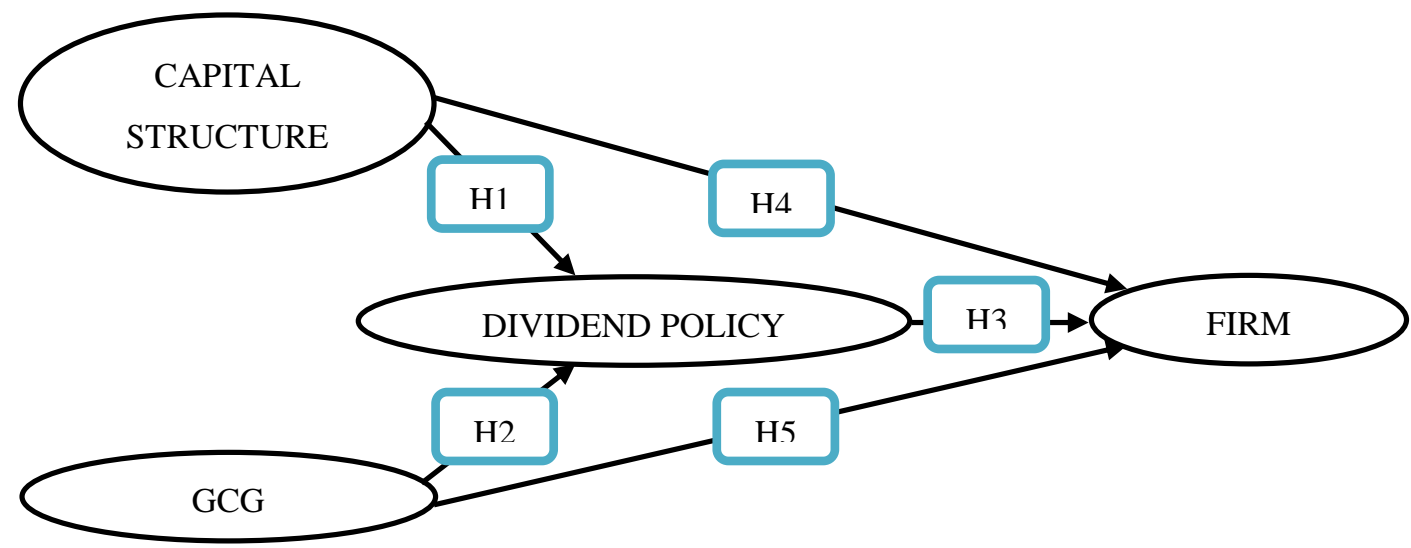

Figure 1 Conceptual Model

\section{METHOD}

This research used explanatory research by using quantitative method. The model and hypothesized relationships were tested using secondary data from annual banking sector firm's financial statements that go public in Indonesia Stock Exchange from 2008 to 2012. The populations of this research are 33 banks that listed in Indonesia Stock Exchange. Observation period was from 2008 to 2012 by using purposive (non-probability) sampling method. Data were collected from 7 banks that chosen as samples in 5 years observation period.

Capital Structure variable measured by Debt Ratio and Debt to Equity Ratio (Sudana, 2011). For the Good Corporate Governance variable, measured using Managerial Ownership and Institutional Ownership (Siallagan and Machfoedz, 2006). Dividend policy is proxied by Dividend Payout Ratio and Dividend Yield (Sudana, 2011). While the firm value is proxied by Return on Investment, Return on Equity, and Price to Book Value (Sunyoto, 2013).

Inferential Statistics are technique used for extrapolating from a set of observations aspects concerning the population as whole. Thus, they attempt to predict the qualities and behavior of a phenomenon which cannot be wholly observed. Inferential statistics bring into play probability theory and reliability of making certain estimates and predictions.

Based on the hypothesis that has been formulated, the analysis of the data used in this study is the Partial Least Square (PLS). According Ghozali (2008) this approach is distribution free and powerful. The means of distribution free is data can be in the form of nominal, category, ordinal, interval and ratio. While understanding power full because PLS does not assume the data should be with a certain scale, and a certain number of samples. PLS analysis can also be used to confirm the theory. This study uses data analysis with PLS as SmartPLS software version 2.0 M3. The reason for the use of PLS as a means of data analysis is to analyze the theory has not been established, because PLS can be used for prediction. Another reason is the PLS is a method of data analysis based on the assumption that samples should not be large, the number of samples is less than 100. Based on a sample calculation has been done, obtained a sample of 35 banks. Then, factor of inadequate data strengthen the use of data analysis tools PLS (Jaya, 2008). 


\section{RESULT AND DISCUSSION}

\section{Descriptive Statistic}

Table 1 Descriptive Statistics

\begin{tabular}{l|r|r|r|r|r}
\hline \hline & N & Min. & Max. & \multicolumn{1}{c|}{ Mean } & $\begin{array}{r}\text { Standard } \\
\text { Deviation }\end{array}$ \\
\hline DR & 35 & .79 & .94 & 0.8949 & .03776 \\
\hline DER & 35 & 3.81 & 15.45 & 9.4891 & 2.87338 \\
\hline IO & 35 & .00 & 82.51 & 35.02 & 21.15142 \\
\hline MO & 35 & .11 & 100.00 & 39.1875 & 34.90277 \\
\hline DY & 35 & .00 & 10.00 & 2.9031 & 2.74671 \\
\hline DPR & 35 & .00 & 90.32 & 27.9704 & 20.80610 \\
\hline ROI & 35 & 1.27 & 21.50 & 3.0894 & 3.31829 \\
\hline ROE & 35 & .17 & 40.65 & 24.3248 & 9.26323 \\
\hline PBV & 35 & .85 & 4.69 & 2.2849 & 1.11535 \\
\hline \hline
\end{tabular}

Descriptive statistics provide an overview of the research object sampled. Explanation of data through descriptive statistics is expected to provide a preliminary description of the problem under study. Descriptive statistics focused on maximum, minimum, mean (average), and standard deviation value.

\section{Outer Model}

Uni-dimensionality a construct evaluated with measurement model (outer model) by using convergent validity, discriminant validity, and composite reliability with latent variables in the path diagram.

1) Convergent Validity

a. Convergent Validity Test of Capital Structure (CS)

Table 2 Outer Loading Result of CS

\begin{tabular}{|c|c|c|c|c|}
\hline & $\begin{array}{c}\text { Original } \\
\text { Sample } \\
(0)\end{array}$ & $\begin{array}{c}\text { Sample } \\
\text { Mean (M) }\end{array}$ & $\begin{array}{l}\text { Standard } \\
\text { Deviation } \\
\text { (STDEV) }\end{array}$ & $\begin{array}{l}\text { T Statistics } \\
(\mid \text { O/STERR|) }\end{array}$ \\
\hline DR $->C S$ & 0.77943 & 0.78261 & 0.07850 & 9.92895 \\
\hline DER $->C S$ & 0.95033 & 0.94635 & 0.06201 & 15.32537 \\
\hline
\end{tabular}

\section{b. Convergent Validity Test of Good}

Corporate Governance (GCG)

Table 3 Outer Loading Result of GCG

\begin{tabular}{lcrrr} 
& $\begin{array}{c}\text { Original } \\
\text { Sample } \\
(\mathbf{O})\end{array}$ & $\begin{array}{c}\text { Sample } \\
\text { Mean (M) }\end{array}$ & $\begin{array}{c}\text { Standard } \\
\text { Deviation } \\
(\text { STDEV) }\end{array}$ & $\begin{array}{c}\text { T Statistics } \\
(\mid \mathbf{O} / \text { STERR|) }\end{array}$ \\
\hline IO <- GCG & 0.96401 & 0.95691 & 0.06520 & 14.78587 \\
\hline MO <- GCG & 0.95853 & 0.95356 & 0.02755 & 34.79140 \\
\hline
\end{tabular}

Table 3 explains the loading factor value of Good Corporate Governance (GCG), which the loading factor value in Institutional Ownership (IO) indicator is 0.964 and Managerial Ownership (MO) is 0.960. This shows that loading factor value in IO and MO indicators are higher than 0.500 so that the indicator in Good Corporate Governance (GCG) variable have explained well by IO and MO or can be explained that this indicator is convergent valid.

\section{c. Convergent Validity Test of Dividend Policy (DP)}

Table 4 Outer Loading Result of DP

\begin{tabular}{lcccc}
\hline & $\begin{array}{c}\text { Original } \\
\text { Sample } \\
(\mathbf{O})\end{array}$ & $\begin{array}{c}\text { Sample } \\
\text { Mean } \\
(\mathbf{M})\end{array}$ & $\begin{array}{c}\text { Standard } \\
\text { Deviation } \\
(\text { STDEV) }\end{array}$ & $\begin{array}{c}\text { T Statistics } \\
(\text { |O/STERR|) }\end{array}$ \\
\hline DY ->DP & 1.148495 & 1.137805 & 0.064536 & 17.796321 \\
\hline DPR ->DP & 1.152052 & 1.141814 & 0.072351 & 15.922994 \\
\hline
\end{tabular}

Table 4 explains the loading factor value of Dividend Policy (DP), which the loading factor value in Dividend Payout Ratio (DPR) indicator is 1.152 and Dividend Yield (DY) is 1.148. This shows that loading factor value in DPR and DY indicators are bigger than 0.500 so that the indicator in Dividend Policy (DP) variable is explained well by DPR and

DY or can be explained that this indicator is

\section{d. Convergent Validity Test of Firm Value} (FV)

Table 2 explains the loading factor value of Capital Structure (CS), which the loading factor value in DR indicator is 0.779 and DER indicator is 0.950 . This shows that loading factor value in DR and DER indicators are bigger than 0.500 , so that the indicator in Capital Structure (CS) variable is explained well by DR and DER indicators or can be explained that this indicator is convergent valid.
Table 5 Outer Loading Result of FV

\begin{tabular}{lcccc} 
& $\begin{array}{c}\text { Original } \\
\text { Sample } \\
(\mathbf{O})\end{array}$ & $\begin{array}{c}\text { Sample } \\
\text { Mean (M) }\end{array}$ & $\begin{array}{c}\text { Standard } \\
\text { Deviation } \\
(\text { STDEV) }\end{array}$ & $\begin{array}{c}\text { T Statistics } \\
(\mid \mathbf{O} / \text { STERR|) }\end{array}$ \\
\hline ROI ->FV & 0.63040 & 0.61240 & 0.20264 & 3.11097 \\
\hline ROE ->FV & 0.95573 & 0.95208 & 0.05608 & 17.04182 \\
\hline PBV ->FV & 0.98136 & 0.97304 & 0.05741 & 17.09371 \\
\hline
\end{tabular}

Table 5 explains the loading factor value of Firm Value (FV), which the loading factor value in PBV indicator is $0.981, \mathrm{ROE}$ indicator 
is 0.956, and ROI is 0.630. This shows that loading factor value in ROI, ROE, and PBV indicators are bigger than 0.500 so that the indicator in Firm Value (FV) variable is explained well by ROI, ROE, and PBV or can be explained that this indicator is convergent valid.

\section{2) Discriminant Validity}

Discriminant validity used to shows indicators of latent variable are different from indicators of other variable, so the indicators can measure the variable properly.

Based on Table 6 it appears that Capital Structure (CS) variable has the highest cross loading factor in Good Corporate Governance (GCG) variable has the highest cross loading factor in IO indicator amounted to 0.964 located in Good Corporate Governance (GCG) variable and MO indicator is 0.958 located in Good Corporate Governance (GCG) variable. This shows that IO and MO explain Good Corporate Governance (GCG) better than other indicator.

\section{Table 6 Cross Loading Result}

\begin{tabular}{lcccc}
\hline & CS & GCG & DP & FV \\
\hline IO & 1.350122 & $\mathbf{1 . 4 6 1 4 7 1}$ & -1.318252 & -1.396145 \\
\hline MO & 1.175862 & $\mathbf{1 . 3 3 7 6 2 8}$ & -1.230563 & -1.254880 \\
\hline
\end{tabular}

Table 7 AVE, Composite Reliability, and Cronbachs Alpha

\begin{tabular}{c|c|c|c}
\hline Variable & AVE & $\begin{array}{c}\text { Composite } \\
\text { Reliability }\end{array}$ & $\begin{array}{c}\text { Cronbachs } \\
\text { Alpha }\end{array}$ \\
\hline GCG & 0.92405 & 0.96053 & 0.94889 \\
\hline
\end{tabular}

Based on Table 7 it appears that AVE value in Good Corporate Governance (GCG) variable is 0.924 that higher than 0.500 , it can conclude that according to discriminant validity, it measurement model has been reached and can be continue to the next step. Composite Reliability in GCG is 0.960 that higher than 0.600 , it can be said that it latent variable has a high reliability. Cronbach Alpha value in GCG is 0.949 that higher than 0.600 , it also can be said that it latent variable has a high reliability.

\section{Inner Model}

After the estimated model was comply with convergent validity criteria and discriminant validity, and then structural model testing was conducted (inner model).

Table 8 R-square Result

\begin{tabular}{cc}
\hline & R Square $\left(\mathbf{R}^{2}\right)$ \\
\hline Dividend Policy (DP) & 0.97865 \\
\hline Firm Value (FV) & 0.98107 \\
\hline
\end{tabular}

Based on Table 8, coefficient of determination ( $R$-square) that obtained by Capital Structure (CS) and Good Corporate Governance (GCG) to Dividend Policy (DP) is 0.979 , then can be explained that Dividend Policy (DP) is effected by Capital Structure (CS) and Good Corporate Governance (GCG) for about $97.9 \%$ and the rest $2.1 \%$ is affected by other variables exclude this observation.

Coefficient of determination ( $R$-square) that obtained by Capital Structure (CS), Good Corporate Governance (GCG), and Dividend Policy (DP) to Firm Value (FV) is 0.981, then can be explained that Firm Value (FV) is affected by Capital Structure (CS), Good Corporate Governance (GCG), and Dividend Policy (DP) for about $98.1 \%$ and the rest $1.9 \%$ is affected by other variables exclude this observation. 


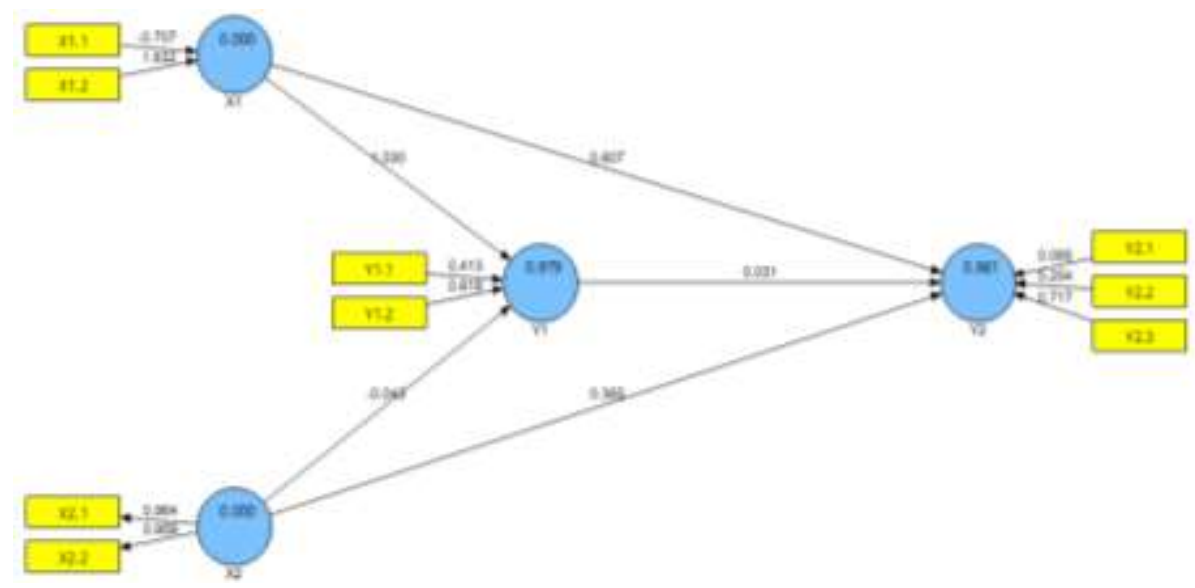

Figure 2 Path Diagram

4. Hypotheses

1) First Hypothesis Testing

H1: Capital Structure Has a Significant Effect on Dividend Policy

Table 9 Testing of Capital Structure (CS) on Dividend Policy (DP)

\begin{tabular}{ccccc}
\hline & $\begin{array}{c}\text { Original } \\
\text { Sample } \\
(\mathbf{O})\end{array}$ & $\begin{array}{c}\text { Sample } \\
\text { Mean } \\
(\mathbf{M})\end{array}$ & $\begin{array}{c}\text { Standard } \\
\text { Deviation } \\
(\text { STDEV })\end{array}$ & $\begin{array}{c}\text { T Statistics } \\
(\mathbf{O} / \mathbf{S T E R} \\
\mathbf{R} \mid)\end{array}$ \\
\hline CS -> DP & 1.02983 & 0.04759 & 21.64208 & 4.075527 \\
\hline
\end{tabular}

Based on the analysis of Table 9, there is a positive correlation with coefficient parameter (1.0298) and significant between Capital Structure (CS) to Dividend Policy (DP) because it has tstatistic value (21.642) higher than t-table (1.960), so the hypothesis $H_{1}$ is accepted. It can be concluded that there is positive and significant effect of Capital Structure (CS) on Dividend Policy (DP) with error tolerance (alpha) is 5\%. The significant positive correlation direction explains that higher Capital Structure (CS) will increase the Dividend Policy (DP).

2) Second Hypothesis Testing

H2: Good Corporate Governance Has a Significant Effect on Dividend Policy

Table 10 Testing of Good Corporate Governance (GCG) on Dividend Policy (DP)

\begin{tabular}{|c|c|c|c|}
\hline $\begin{array}{l}\text { Original } \\
\text { Sample } \\
\text { (O) }\end{array}$ & $\begin{array}{l}\text { Sample } \\
\text { Mean } \\
\text { (M) }\end{array}$ & $\begin{array}{l}\text { Standard } \\
\text { Deviation } \\
\text { (STDEV) }\end{array}$ & $\begin{array}{c}\text { T Statistics } \\
\text { (|O/STERR|) }\end{array}$ \\
\hline
\end{tabular}

\begin{tabular}{lllll}
\hline GCG -> DP & -0.04290 & 0.04991 & 0.85942 & 6.804431 \\
\hline
\end{tabular}

Based on the analysis result of Table 10, there is a negative correlation with the coefficient parameter $(-0.043)$ but not significant between Good Corporate Governance (GCG) and Dividend Policy (DP) because it has a t-statistic value (0.859) that lower than t-table value (1.960), so the hypothesis $H_{1}$ is rejected ( $\mathrm{H}_{0}$ is accepted). It can be concluded that there is a negative but not significant effect of Good Corporate Governance (GCG) on Dividend Policy (DP) with error tolerance (alpha) is 5\%. The non-significant negative correlation directions explain that higher and lower of Good Corporate Governance (GCG) will not increase or decrease the Dividend Policy (DP) level.

\section{3) Third Hypothesis Testing \\ H3: Dividend Policy Has a Significant Effect on Firm Value}

Table 11 Testing of Dividend Policy (DP) on Firm Value (FV)

\begin{tabular}{ccccc}
\hline & $\begin{array}{c}\text { Original } \\
\text { Sample } \\
(\mathbf{O})\end{array}$ & $\begin{array}{c}\text { Sample } \\
\text { Mean } \\
(\mathbf{M})\end{array}$ & $\begin{array}{c}\text { Standard } \\
\text { Deviation } \\
(\mathbf{S T D E V})\end{array}$ & $\begin{array}{c}\text { T } \\
\text { Statistics } \\
(\mid \mathbf{O} / \text { STER } \\
\mathbf{R} \mid)\end{array}$ \\
\hline $\mathrm{DP}->\mathrm{FV}$ & 0.03098 & 0.11485 & 0.26978 & 3.010632 \\
\hline
\end{tabular}

Based on the analysis result of Table 11 there is a positive correlation with the coefficient parameter (0.031) but not significant between Dividend Policy (DP) and Firm Value (FV) because it has tstatistic value $(0.270)$ is lower than the 
value of t-table (1.960), so the hypothesis $\mathrm{H}_{1}$ is rejected $\left(\mathrm{H}_{0}\right.$ is accepted). It can be concluded that there is positive but not significant effect of Dividend Policy (DP) on Firm Value (FV) with error tolerance (alpha) is 5\%. Non-significant positive correlation direction explains that the higher and lower Dividend Policy (DP) will not increase or decrease the Firm Value (FV) level.

\section{4) Fourth Hypothesis Testing}

H4: Capital Structure Has a NonSignificant Effect on Firm Value

Table 12 Testing of Capital Structure (CS) on Firm Value (FV)

\begin{tabular}{lcccr}
\hline & $\begin{array}{c}\text { Original } \\
\text { Sample } \\
(\mathbf{O})\end{array}$ & $\begin{array}{c}\text { Sample } \\
\text { Mean } \\
(\mathbf{M})\end{array}$ & $\begin{array}{c}\text { Standard } \\
\text { Deviation } \\
(\text { STDEV) }\end{array}$ & $\begin{array}{c}\text { T Statistics } \\
(\mid \mathbf{O} \text { /STERR|) }\end{array}$ \\
\hline $\mathrm{CS}->\mathrm{FV}$ & 0.60686 & 0.13634 & 4.45095 & 0.692871 \\
\hline
\end{tabular}

Based on the analysis result of Table 12 , there is a positive correlation with the parameter coefficient (0.607) and significant between Capital Structure (CS) and Firm Value (FV) because it has tstatistic value (4.451) that higher than $\mathrm{t}$ table (1.960), so the hypothesis $\mathrm{H}_{1}$ is accepted. It can conclude that there is a positive and significant effect of Capital Structure (CS) on Firm Value (FV) with an error tolerance (alpha) is 5\%. Significant positive correlation direction explains that the level of Capital Structure (CS) will increase the Firm Value (FV).

\section{5) Fifth Hypothesis Testing}

H5: Good Corporate Governance Has a Significant Effect on Firm Value

Table 13 Testing of Good Corporate Governance (GCG) on Firm Value (FV)

\begin{tabular}{ccccc}
\hline & $\begin{array}{c}\text { Original } \\
\text { Sample } \\
(\mathbf{O})\end{array}$ & $\begin{array}{c}\text { Sample } \\
\text { Mean } \\
(\mathbf{M})\end{array}$ & $\begin{array}{c}\text { Standard } \\
\text { Deviation } \\
(\text { STDEV) }\end{array}$ & $\begin{array}{c}\text { T } \\
\text { Statistics } \\
(\mathbf{| O / S T E} \\
\mathbf{R R})\end{array}$ \\
\hline GCG ->FV & 0.36521 & 0.05317 & 6.86919 & 7.923117 \\
\hline
\end{tabular}

Based on the analysis result of Table 13 , there is a positive correlation with the parameter coefficient (0.365) and significant between Good Corporate Governance (GCG) and Firm Value (FV) because it has a value of $t$-statistic value
(6.869) that higher than t-table value (1.960), so the hypothesis $\mathrm{H}_{1}$ is accepted, it can be concluded that there is positive and significant effect of Good Corporate Governance (GCG) on Firm Value (FV) with a error tolerance (alpha) is 5\%. Significant positive correlation direction explains that higher of Good Corporate Governance (GCG) will increase the Firm Value (FV).

\section{Discussion}

\section{1) The Effect of Capital Structure on} Dividend Policy

The first hypothesis testing result shows that there is a positive and significant effect of capital structure on dividend policy. The significant positive effect direction explain that the higher capital structure will increase the dividend policy value, conversely the lower capital structure value will decrease the dividend policy value in banking company listed in Indonesia Stock Exchange for observation period $2008-2012$.

Determining the optimal capital structure target is the main duty of company's management. Capital structure is the funding proportion with company's debt (debt financing), i.e. leverage ratio. So that debt is the main item of company's capital structure. Decisions regarding capital structure have farreaching consequences that frequently affect a company's dividend policy. Companies prefer to use more debt for dividend payment, rather than for operating expenditure and capital expenditure. The connections between capital structure and dividend policy becomes more complex because the high amount of capital structure from debt could be spending for dividend payment rather than spending for operating and capital expenditure. There is a chance to reach a higher dividend payment from the external funding sources. Increasing in spending debt for dividend payment could decrease the amount of cash available for operating and capital expenditures. In the other word, increasing debt is followed by increasing for dividend payment, because debt is spending more for dividend payment rather than for operating and capital expenditure. The higher funding source from debt is the higher dividend payment spending in company's shareholders.

This research result found that there is a positive and significant effect of capital structure on dividend policy. This result also 
supported by Sudiyatno, et al (2012) who stated that capital expenditure from debt has a significant positive effect on the level of significance of the company performance that measured by dividend payment. A different result found by Al-Kuwari (2009) who stated that the main characteristics of firm dividend payout policy were that dividend payment related strongly and directly negative to the leverage ratio.

\section{2) The Effect of Good Corporate Governance on Dividend Policy}

The second hypothesis testing result shows that there is a negative but not significant effect of Good Corporate Governance on dividend policy in banking company listed in Indonesian Stock Exchange for the observation period 2008 $-2012$.

The relationship between Good Corporate Governance and dividend policy is related with the monitoring and controlling management of the free cash available to pay dividend or retained for re-invested by the company. In one company accounting period, there is free cash that available after reduced by operating and capital expenditure, named free cash flow. Free cash flow reflects the cash flow rate of return for the investor, both in the form of debt or equity. Free cash flow can be used to pay down debt, share repurchase, dividend payment, or saved for future company growth opportunities.

Much research concludes that dividends can serve as a signal of the company to public investors about the condition of the company. However admitted that the dividend payments require significant funding, and once dividend is paid then it is difficult for companies to reduce the amount of dividends paid as if this is the case then the investor will respond negatively. When dividends serve as a way for managers to provide a marker of management commitment to the creation of value in the future, it is not necessary to pay dividends in large quantities. Commitment to shareholder value will be ensured through the mechanisms of Good Corporate Governance (GCG). Laporta et al. (2000) refers to this as an Argument Substitution. Based on the argument substitution, dividend payments may have an impact on the reduction of agency costs by forcing companies to act in accordance with the capital market discipline. With corporate governance mechanisms will effectively oversee the management, so that the company can reduce the function of the dividend as a marker to pay fewer dividends (Kanagaretman, Lobo, and Whalen, 2007; John and Knyazeva, 2006; Han et al., 1999).

This research result found that there is a negative but not significant effect of Good Corporate Governance on dividend policy. Several research proving this hypothesis include Officer (2006), Pan (2007), Jiraporn and Kim (2010) who reported a negative influence between corporate governance and dividend payout ratio, in this case the corporate governance measured by Governance Index developed by Gompers, et al. (2001). While John and Knyazeva (2006), using a broader indices such as board structure (board account structure), institutional block holding, and the index of Gompers, et al. (2001) also proved the existence of a substitution effect between governance quality and dividend payout ratio. They also stated that firms with weak Corporate Governance on average pay higher dividends with the relation between dividend and governance is stronger for firms with high free cash flow. This is consistent with the existence of a coalition of shareholders, where the higher the shareholder coalition that serves as a counterweight to the controlling shareholder, will reduce the dividend function as a marker/signal about the state of the company for investors.

A different result found by Al-Kuwari (2009) who stated that the main characteristics of firm dividend payout policy were that dividend payment related strongly and directly to government ownership. In a line with Mitton (2004) conducted research on corporate governance and dividends in developing countries. The results showed that relationship between GCG and dividend policy is positive, especially in countries that have the protection of investors. These findings also stated level of corporate governance and investor protection are complementary rather than substitutes.

\section{3) The Effect of Dividend Policy on Firm Value}

The third hypothesis testing result shows that there is a positive but not significant of dividend policy on firm value of banking company listed in Indonesia Stock Exchange for the observation period 2008 - 2012.

According to Brigham (1989), he stated that there are 3 (three) theories of dividend policy, one of which is the Dividend Irrelevance 
Theory. The non-significant effect between dividend policy and firm value indicate the presence of this theory. This theory states that the company's dividend policy does not constitute an influence on the value of the company as well as the cost of capital. The main supporters of Dividend Irrelevance Theory is Merton Miller and Franco Modigliani (2001). They argue that a company's value is determined only by the ability to generate profits and basically its business risk. In other words, the value of the company depends only on the income generated by the assets, rather than on how the revenue is split between dividends and retained earnings. Keon et al. (2000) stated that the Dividend Irrelevance Theory, there is no relationship between dividend policy and stock value. A dividend policy is as good as another. In aggregate investors are only concerned with the total return on investment decisions, regardless of whether the return is derived from capital gains or dividend income.

This research result found that there is a positive but not significant effect of dividend policy on firm value. A similar result also found by Pan (2007), who stated that dividend policy is jointed determined with other corporate decisions and could potentially have first-order importance to shareholder value.

\section{4) The Effect of Capital Structure on Firm Value}

The fourth hypothesis testing result shows that there is a positive and significant effect of capital structure on firm value. The significant positive effect direction explain that the higher capital structure value will increase the firm value, conversely the lower capital structure value will decrease the firm value of banking company listed in Indonesia Stock Exchange for the observation period 2008 - 2012.

This result also in a line with Signaling Theory which state companies that use more debt provide a more credible signal to the investor. Because companies are increasing debt can be viewed as companies that believe in the company's prospects in the future. Investors are expected to capture the signal, a signal that the company has good prospects.

This research result found that there is a positive and significant effect of capital structure on firm value. One of the company's efforts to improve and maintain the performance of the company's capital structure is to measure the ability in managing the funding proportion with company's debt (debt financing). Capital structure is an important issue for firms, because as good to poor capital structure has direct effects on the value position of the firm, which in turn will affect the value of the firm. A similar result found by Pan (2007) who stated that dividend policy is jointed determined with other corporate decisions and could potentially have first-order importance to shareholder value.

\section{5) The Effect of Good Corporate Governance on Firm Value}

The fifth hypothesis testing result shows that there is a positive and significant effect of Good Corporate Governance on firm value. The significant positive effect direction explain that the higher Good Corporate Governance value will increase the firm value, conversely the lower of Good Corporate Governance value will also decrease the firm value of banking company listed in Indonesia Stock Exchange for the observation period $2008-2012$.

Corporate governance is a controlling mechanism to regulate and manage the firms in order to increasing prosperity and corporate accountability, which finally goal is to create shareholder value (Monk and Minow, 2004). According to the World Bank (2010), corporate governance controlling mechanisms is divided into two, namely internal and external mechanisms. External mechanisms include the following: capital markets, funders, consumers, regulators. Meanwhile, the internal mechanism is comprised of: a control carried out by the board of commissioners, including committees under it; the board of directors; management and shareholders; or through an attractive incentive scheme for management and competitive.

The existence of information asymmetry between managers and shareholders, move by the connection with the separation between owners and managers. This condition is the basis for the establishment of other explanations why dividend policy to be a thorny issue. This argument is based on the assumption that managers may behave opportunistic indicated with activities that only serve the interests of their own which is not always beneficial to the shareholders (Jensen, 1976). Managerial opportunism hypothesis as expressed by (Jensen, 1986; Jiraporn and Ning, 2006) states that managers have tended to hold cash in the 
company, which provides them to consume more extra income, to use in building the kingdom, and to invest in projects with revenues only increase their personal prestige but does not benefit shareholders.

This suggests that not all of managerial owners wants high investment, but also wants prosperity through the dividend payment. This is one of opportunistic act of managerial owner, managerial owner wants a high income rather than the growth of company's investment. To avoid this managerial owner opportunistic action, companies could add a huge amount of institutional ownership that owned by institutional owner. The high institutional owner would maximize the controlling and managing of the company. The high controlling by institutional owner would minimize the opportunistic act of managerial owner that caused the firm value decreasing. The lower degree of misappropriation of abuses committed by the management will result in an increasing in trust of investors and shareholder, thus will increase the firm value.

This research result found that there is a positive and significant effect of Good Corporate Governance on firm value. A similar result found by Chen, et al (2003), who stated that firm value which proxied by Tobin's Q increases monotonically with managerial ownership. A different result found by Fuzuli, et al (2013), who stated that managerial ownership and institutional ownership had negative effect to firm value.

\section{Limitations and Future Research}

Some limitation of this research and recommendation about future research:

1. The research using 2 (two) indicators that reflect Good Corporate Governance (GCG) variable, which are Institutional Ownership (IO) and Managerial Ownership (MO) with reflective index. Researcher using these indicators because both of these indicators are explained well the Good Corporate Governance (GCG) in Indonesia banking sector companies which some ownership shares owned by family ownership.

2. The numbers of samples is not determined randomly, but using purposive sampling which requires some specific criteria. The sample of this research is limited only for banking companies, the research result cannot generalize for other sector outside banking company.
3. The numbers of samples of this research is 35 samples, samples is took from 7 (seven) company in 5 (five) years observation period in 2008 - 2012. The least of this sample caused due to some constraint, among others, the incomplete company's financial report, the lack of institutional and managerial ownership, and no cash dividend distributed either. This condition led to a number of companies excluded from the samples because did not meet the selection criteria of sample set.

\section{CONCLUSION REMARK}

\section{Conclusion}

1) Capital structure has positive and significant effect on dividend policy. This shows that the higher capital structure will increase the dividend policy value, conversely the lower capital structure value will decrease the dividend policy value. Companies prefer to use more debt for dividend payment, rather than operating expenditure and capital expenditure. The connections between capital structure and dividend policy becomes more complex because decreasing in spending debt for operating and capital expenditures could increase the amount of cash available for dividend payment. In the other word, increasing debt is followed by increasing for dividend payment, because debt is spending more for dividend policy rather than for operating and capital expenditure. Capital's company that comes from debt is used for dividend payment to shareholders, so there is a possibility to get higher dividend from external funding sources.

2) Good Corporate Governance has negative but not significant effect on dividend policy. When dividends serve as a way for managers to provide a marker of management commitment to the creation of value in the future, it is not necessary to pay dividends in large quantities. Commitment to shareholder value will be ensured through the mechanisms of Good Corporate Governance (GCG). Based on the argument substitution, dividend payments may have an impact on the reduction of agency costs by forcing companies to act in accordance with the capital market discipline. With corporate governance mechanisms will effectively oversee the management, so that the 
company can reduce the function of the dividend as a marker to pay fewer dividends. This is consistent with the existence of a coalition of shareholders, where the higher the shareholder coalition that serves as a counterweight to the controlling shareholder, will reduce the dividend function as a marker/signal about the state of the company for investors.

3) Dividend policy has positive but not significant effect on firm value. This positive correlation suggests that high dividends indicate that the company is good. Dividend payment is a positive signal for investors. The high of dividend payment can be perceived by the investor as the ability of the company to prosper the investor or shareholder. Besides increasing the prosperity of the investor, high dividend payment reflects the company's good performance managers. Ability to pay dividends is also closely related to the ability of firms makes a profit. If the firm makes a large profit, the ability to pay dividends is also great. This perception of investors or shareholders can raise the value of company.

4) Capital structure has positive and significant effect on firm value. This shows that the higher capital structure value will increase the firm value, conversely the lower capital structure will decrease the firm value. Capital structure has an influence on the value of the company, in which the capital structure may change in order to obtain optimal firm value. Capital structure is an important issue for firms, because as good to poor capital structure has direct effects on the value position of the firm, which in turn will affect the value of the firm. Management of the capital structure also give signal to the investor, companies are increasing debt can be viewed as companies that believe in the company's prospects in the future. Investors are expected to capture the signal, a signal that the company has good prospects.

5) Good Corporate Governance has positive and significant effect on firm value. This shows that the higher Good Corporate Governance value will increase the firm value, conversely the lower of Good Corporate Governance value will also decrease the firm value. This suggests that a huge amount of institutional ownership that owned by institutional owner can improve the controlling mechanism and reduce the opportunistic and the misappropriate act of managerial owner. The high institutional owner would maximize the controlling and managing of the company. The high controlling by institutional owner would minimize the opportunistic act of managerial owner that caused the firm value decreasing. The lower degree of misappropriation of abuses committed by the management will result in an increasing in trust of investors and shareholder, thus will increase the firm value.

\section{Remark}

1) Suggested for company's manager must to attempt to keep a balance between capital structure and dividend policy. If companies want to increase their firm value, suggested to optimal the capital structure and put a high controlling of Good Corporate Governance mechanism. And when determining capital structure, company's manager is suggested should not to use too big debt for financing. Using too big debt making companies the more burdened in payment of interest charges that pose the higher risk of bankruptcy. As far as the benefit is higher, then the additional debt is still allowed. Conversely, if the sacrifice because the use of debt is higher, then the additional debt is not allowed. Finally, if companies want to increase their firm value, company's manager is suggested raising their institutional and managerial ownership.

2) Suggested for future research using the number of samples not only banking company, but also the non-banking company, so that the research is expected to deliver the result that can be generalized to the entire company in Indonesia. Research time period can also be extended and with a larger sample number and variety. Extension of the period of the sample will probably give better result in estimates relationship of each variable. This research used only capital structure and Good Corporate Governance variable to determine its effect on dividend policy and firm value of the company. It is suggested for future research to examine other financial variables that probably have greater effect on dividend policy and firm value. It is also suggested to examine the indicators of Good Corporate 
Governance in full in order to get a best description and result for the research.

3) Suggested for investor to analyze the financial condition, assessing the financial posts related to dividend to be distributed and firm value obtained by the company

\section{REFERENCES}

Al-Kuwari, Duha. 2009. Determinants of the Dividend Policy in Emerging Stock Exchanges: The Case of GCC Country. Global Economy and Finance Journal Vol. 2 (2): 38-63.

Allen, Franklin and Gale, Douglas. 2001. Do Financial Institutions Matter?. The Journal of Finance Vol. VI (4): 11651175.

Brigham and Houston. 2006. Fundamental of Financial Management. 10th Edition. Jakarta: Salemba Empat.

Brigham, E. F. and Daves, P. R. 2007. Intermediate Financial Management. Ninth Edition. Mason: South-Western Cengage Learning.

Brigham, E. F. and Ehrhardt, M.C. 2005. Financial Management: Theory and Practice. International Student Edition. Ohio: South-Western Thomson.

Chen, C. R., Guo, W., and Mande, V. 2003. Managerial Ownership and Firm Valuation: Evidence from Japanese Firms. Pacific-Basin Finance Journal Vol. 11 (2003): 267-283.

Fama, Eugene F. and French, Kenneth R. 1998. Taxes, Financing Decision, and Firm Value. Journal of Finance Vol LIII (3): 819-843.

Fuzuli, M.I., Pahala, I., and Murdayanti, Y. 2013. The Influence of Good Corporate Governance and Earnings Management on Firm Value. Abstract International Conference on Business and Economic Research (ICBER) Proceeding.

Gompers, Paul A.; Ishii, Joy L; and Metrick, Andrew. 2001. Corporate Governance and Equity Prices. Abstract NBER Working Paper, No. 8449. August, JEL No. G3. (should be consider another aspects before investment).

Suggested for BI, it is advisable to limit the portion of share ownership by family owned, in order to create good governance and balanced ownership in order to create checks and balances.

Jaya, I Gede Nyoman Mindra and Sumertajaya, I Made. 2008. Pemodelan Persamaan Struktural dengan Partial Least Square. Seminar Nasional Matematika dan Pendidikan Matematika: 118-132.

Jensen, Michael C. 1986. Agency Costs of Free Cash Flow, Corporate Finance, and Takeovers. American Economic Review Vol. 76: 23-329.

Jensen, Michael C. and Meckling, William H. 1976. Theory of The Firm: Managerial Behavior, Agency Cost and Ownership Structure. Journal of Financial Economics Vol. 3 (4): 305-360.

Jensen, Michael C. and Smith, Jr Clifford W. 1994. The Modern Theory of Corporate Finance. Mc Graw - Hill Book Company.

Jiraporn, P., Kim, Y. S., and Kim, J.C. 2010. Dividend Policy and Corporate Governance Quality: Evidence from ISS. Abstract The Financial Review, G30, G32, G34.

Jiraporn, Pornsit and Yixi, Ning. 2006. Dividend Policy, Shareholder Rights, and Corporate Governance. Journal of Applied Finance - Fall/winter 2006.

John, Kose and Knyazeva, Anzhela. 2006. Payout Policy, Agency Conflict, and Corporate Governance. Abstract, May, New York.

Kaplan, Steven N. 1998. Top Executive Incentives in Germany, Japan and U.S.: A Comparison. Journal for Conference on Executive Compensation and Shareholder Value, February.

Keown, A. J., Martin, J. H., Petty, J. W., and Scott, D. F. 2004. Financial Management: Principles and Applications. 10th Edition. New Jersey: Prentice Hall. 
Mayer, Colin. 1996. Corporate Governance, Competition and Performance. Abstract Economic Departement Working Papers, No. 164.

Mbodja, M. and Mukherjee, Tarunk. 1994. An Investigation Into Causality Among Firms' Dividend, Invesment, \& Financing Decision. Journal of Financial Research, pp. 517-530.

Monks, Robert A. G. and Minow, N. 2004. Corporate Governance. Third Edition. Malden: Blackwell Publishing.

OECD. 2003. White Paper On Corporate Governance in Asia.

Officer, Micah S. 2006. Dividend Policy, Dividend Initiations, and Governance. Abstract, October.

Pan, Carrie H. 2007. Two Essays in Corporate Finance. Dissertation.

Qureshi, M.A and Azid, Toseef. 2006. Did They Do It Differently? Capital Structure Choices of Public and Private Sectors in Pakistan. Journal of The Pakistan Development Review, 45: 4, Part II, pp. 701-709.

Qureshi, Muhammad Azeem. 2006. System Dynamics Modelling on Firm Value. Journal of Modelling in Management Vol. 2 (1): 24-39.

Shleifer, Andrei and Vishny, R. W. 1996. A Survey of Corporate Governance. NBER Working Paper Series.
Cambridge: National Bureau of Economic Research.

Siallagan, Hamonangan and Machfoedz, Mas'ud. 2006. Mekanisme Corporate Governance, Kualitas Laba dan Nilai Perusahaan. Accounting National Symposium IX. Padang. August 23-26.

Simanjutak, Djisman S. 2001. Transition to Good Governance in Post-Crisis Indonesia: High Barriers and Windows of Opportunities. Abstract, Second Draft, March.

Sudana, I Made. 2011. Manajemen Keuangan Perusahaan Teori dan Praktik. Jakarta: Erlangga.

Sudiyatno, B., Puspitasari, E., Kartika, A. 2012. The Company's Policy, Firm Performance, and Firm Value: An Empirical Research on Indonesian Stock Exchange. American International Journal of Contemporary Research Vol. 2 (12): 30-40.

Sunyoto, Danang. 2013. Analisis Laporan Keuangan Bisnis: Teori dan Kasus. Yogyakarta: CAPS.

The World Bank. 2010. Report on the Observance of Standards and Codes: Corporate Governance Country Assessment, Indonesia.

Yermack, David. 1996. Higher Market Valuation of Companies with A Small Board of Directors. Journal of Financial Economics (40): 185-211. 


\section{APPENDICES}

APPENDIXE 1: Descriptive Statistic

Descriptive Statistics

\begin{tabular}{|c|c|c|c|c|c|}
\hline & $\mathrm{N}$ & Minimum & Maximum & Mean & Std. Deviation \\
\hline$X 1.1$ & 35 & .7900 & .9400 & 0.894857 & .0377586 \\
\hline$X 1.2$ & 35 & 3.8100 & 15.4500 & 9.489143 & 2.8733802 \\
\hline X2.1 & 35 & .0000 & 82.5100 & 35.021830 & 21.1514211 \\
\hline $\mathrm{X} 2.2$ & 35 & .1100 & 100.0000 & 39.187510 & 34.9027641 \\
\hline Y1.1 & 35 & .0000 & 10.0000 & 2.903143 & 2.7467101 \\
\hline Y1.2 & 35 & .0000 & 90.3200 & 27.970420 & 20.8060992 \\
\hline Y2.1 & 35 & 1.2700 & 21.5000 & 3.089429 & 3.3182880 \\
\hline Y2.2 & 35 & .1695 & 40.6500 & 24.324840 & 9.2632345 \\
\hline Y2.3 & 35 & .8500 & 4.6900 & 2.284857 & 1.1153458 \\
\hline Valid N (listwise) & 35 & & & & \\
\hline
\end{tabular}

APPENDIXE 2: Outer Model

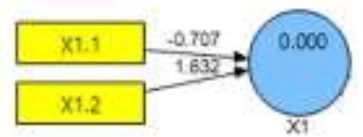

Outer Weights of Capital Structure

Outer Weights Result of Capital Structure (CS) Variable

\begin{tabular}{lrrrrr} 
& $\begin{array}{c}\text { Original } \\
\text { Sample (O) }\end{array}$ & $\begin{array}{c}\text { Sample } \\
\text { Mean (M) }\end{array}$ & $\begin{array}{l}\text { Standard } \\
\text { Deviation } \\
\text { (STDEV) }\end{array}$ & $\begin{array}{c}\text { Standard } \\
\text { Error } \\
\text { (STERR) }\end{array}$ & \multicolumn{1}{c}{$\begin{array}{c}\text { T Statistics } \\
\text { (|O/STERR|) }\end{array}$} \\
\hline DR ->CS & -0.70721 & -0.70030 & 0.05672 & 0.05672 & 12.46804 \\
\hline DER ->CS & 1.63231 & 1.64044 & 0.10895 & 0.10895 & 14.98184 \\
\hline
\end{tabular}

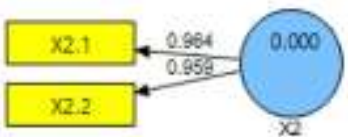

Outer Weights of Good Corporate Governance

Outer Weights Result of Good corporate Governance (GCG) Variable

\begin{tabular}{lccccr} 
& $\begin{array}{c}\text { Original } \\
\text { Sample (O) }\end{array}$ & $\begin{array}{c}\text { Sample } \\
\text { Mean (M) }\end{array}$ & $\begin{array}{c}\text { Standard } \\
\text { Deviation } \\
\text { (STDEV) }\end{array}$ & $\begin{array}{c}\text { Standard } \\
\text { Error } \\
\text { (STERR) }\end{array}$ & $\begin{array}{c}\text { T Statistics } \\
\text { (|O/STERR|) }\end{array}$ \\
\hline IO <- GCG & 0.96401 & 0.95691 & 0.06520 & 0.06520 & 14.78587 \\
\hline MO <- GCG & 0.95853 & 0.95356 & 0.02755 & 0.02755 & 34.79140 \\
\hline
\end{tabular}

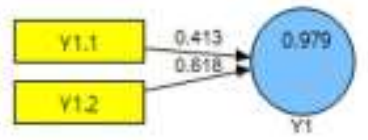

Outer Weights of Dividend Policy

Outer Weights Result of Dividend Policy (DP) Variable

\begin{tabular}{lccccr}
\hline & $\begin{array}{c}\text { Original } \\
\text { Sample (O) }\end{array}$ & $\begin{array}{c}\text { Sample } \\
\text { Mean (M) }\end{array}$ & $\begin{array}{c}\text { Standard } \\
\text { Deviation } \\
\text { (STDEV) }\end{array}$ & $\begin{array}{c}\text { Standard } \\
\text { Error } \\
\text { (STERR) }\end{array}$ & \multicolumn{1}{c}{$\begin{array}{c}\text { T Statistics } \\
\text { (|O/STERR|) }\end{array}$} \\
\hline DY ->DP & 0.41308 & 0.40239 & 0.06342 & 0.06342 & 6.51394 \\
\hline DPR ->DP & 0.61793 & 0.64670 & 0.10219 & 0.10219 & 6.04669 \\
\hline
\end{tabular}




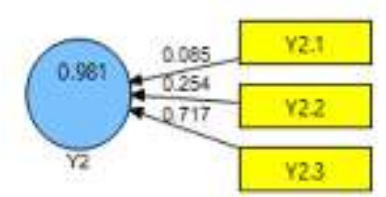

Outer Weights of Firm Value

Outer Weights Result of Firm Value (FV) Variable

\begin{tabular}{lccccc}
\hline & $\begin{array}{c}\text { Original } \\
\text { Sample (O) }\end{array}$ & $\begin{array}{c}\text { Sample } \\
\text { Mean (M) }\end{array}$ & $\begin{array}{c}\text { Standard } \\
\text { Deviation } \\
\text { (STDEV) }\end{array}$ & $\begin{array}{c}\text { Standard } \\
\text { Error } \\
\text { (STERR) }\end{array}$ & $\begin{array}{c}\text { T Statistics } \\
\text { (|O/STERR|) }\end{array}$ \\
\hline ROI ->FV & 0.08542 & 0.22455 & 0.54617 & 0.54617 & 0.15640 \\
\hline ROE ->FV & 0.25375 & 0.28395 & 0.15041 & 0.15041 & 1.68709 \\
\hline PBV ->FV & 0.71700 & 0.66370 & 0.15752 & 0.15752 & 4.55179 \\
\hline
\end{tabular}

\section{APPENDIX 3: PLS Testing Result}

Outer Loadings (Mean, STDEV, T-Values)

\begin{tabular}{|c|c|c|c|c|c|}
\hline & $\begin{array}{l}\text { Original } \\
\text { Sample }(\mathrm{O})\end{array}$ & $\begin{array}{l}\text { Sample } \\
\text { Mean (M) }\end{array}$ & $\begin{array}{l}\text { Standard Deviation } \\
\text { (STDEV) }\end{array}$ & $\begin{array}{l}\text { Standard Error } \\
\text { (STERR) }\end{array}$ & $\begin{array}{l}\text { T Statistics } \\
(|\mathrm{O} / \mathrm{STERR}|)\end{array}$ \\
\hline$X 1.1->X 1$ & 0.77943 & 0.78261 & 0.07850 & 0.07850 & 9.92895 \\
\hline X1.2 -> X1 & 0.95033 & 0.94635 & 0.06201 & 0.06201 & 15.32537 \\
\hline$X 2.1<-X 2$ & 0.96401 & 0.95691 & 0.06520 & 0.06520 & 14.78587 \\
\hline$X 2.2<-X 2$ & 0.95853 & 0.95356 & 0.02755 & 0.02755 & 34.79140 \\
\hline Y1.1 -> Y1 & 0.96208 & 0.95003 & 0.08992 & 0.08992 & 10.69954 \\
\hline Y1.2 -> Y1 & 0.97517 & 0.96739 & 0.08045 & 0.08045 & 12.12146 \\
\hline Y2.1 -> Y2 & 0.63040 & 0.61240 & 0.20264 & 0.20264 & 3.11097 \\
\hline Y2.2 -> Y2 & 0.95573 & 0.95208 & 0.05608 & 0.05608 & 17.04182 \\
\hline Y2.3 -> Y2 & 0.98136 & 0.97304 & 0.05741 & 0.05741 & 17.09371 \\
\hline
\end{tabular}

Outer Weights (Mean, STDEV, T-Values)

\begin{tabular}{|c|c|c|c|c|c|}
\hline & $\begin{array}{l}\text { Original } \\
\text { Sample (O) }\end{array}$ & $\begin{array}{l}\text { Sample } \\
\text { Mean (M) }\end{array}$ & $\begin{array}{l}\text { Standard Deviation } \\
\text { (STDEV) }\end{array}$ & $\begin{array}{l}\text { Standard Error } \\
\text { (STERR) }\end{array}$ & $\begin{array}{l}\text { T Statistics } \\
(|\mathrm{O} / \mathrm{STERR}|)\end{array}$ \\
\hline$X 1.1->X 1$ & -0.70721 & -0.70030 & 0.05672 & 0.05672 & 12.46804 \\
\hline$X 1.2->X 1$ & 1.63231 & 1.64044 & 0.10895 & 0.10895 & 14.98184 \\
\hline$X 2.1<-X 2$ & 0.54907 & 0.55122 & 0.01899 & 0.01899 & 28.91151 \\
\hline$X 2.2<-X 2$ & 0.49105 & 0.49707 & 0.03335 & 0.03335 & 14.72630 \\
\hline$Y_{1} 1.1->Y_{1}$ & 0.41308 & 0.40239 & 0.06342 & 0.06342 & 6.51394 \\
\hline $\mathrm{Y} 1.2->\mathrm{Y} 1$ & 0.61793 & 0.64670 & 0.10219 & 0.10219 & 6.04669 \\
\hline$Y 2.1->Y 2$ & 0.08542 & 0.22455 & 0.54617 & 0.54617 & 0.15640 \\
\hline$Y 2.2->Y 2$ & 0.25375 & 0.28395 & 0.15041 & 0.15041 & 1.68709 \\
\hline$Y 2.3$-> Y2 & 0.71700 & 0.66370 & 0.15752 & 0.15752 & 4.55179 \\
\hline
\end{tabular}


Path Coefficients (Mean, STDEV, T-Values)

\begin{tabular}{|l|r|r|r|r|r|}
\hline & \multicolumn{1}{|c|}{$\begin{array}{l}\text { Original } \\
\text { Sample (O) }\end{array}$} & $\begin{array}{l}\text { Sample } \\
\text { Mean (M) }\end{array}$ & $\begin{array}{l}\text { Standard Deviation } \\
\text { (STDEV) }\end{array}$ & $\begin{array}{l}\text { Standard Error } \\
\text { (STERR) }\end{array}$ & $\begin{array}{l}\text { T Statistics } \\
\text { (|O/STERR|) }\end{array}$ \\
\hline $\mathrm{X} 1$-> Y1 & 1.02983 & 1.02314 & 0.04759 & 0.04759 & 21.64208 \\
\hline $\mathrm{X} 1$-> Y2 & 0.60686 & 0.61019 & 0.13634 & 0.13634 & 4.45095 \\
\hline $\mathrm{X} 2$-> Y1 & -0.04290 & -0.03560 & 0.04991 & 0.04991 & 0.85942 \\
\hline $\mathrm{X} 2$-> Y2 & 0.36521 & 0.37230 & 0.05317 & 0.05317 & 6.86919 \\
\hline $\mathrm{Y} 1$-> Y2 & 0.03098 & 0.02082 & 0.11485 & 0.11485 & 0.26978 \\
\hline
\end{tabular}

\section{Overview}

\begin{tabular}{|l|l|r|r|r|r|r|}
\hline & AVE & Composite Reliability & R Square & Cronbachs Alpha & Communality & Redundancy \\
\hline X1 & & & & & 0.77932 & \\
\hline X2 & 0.92405 & & & 0.94889 & 0.98283 & \\
\hline Y1 & & & 0.96053 & & 0.99137 & 0.15711 \\
\hline Y2 & & & 0.97865 & & 0.92082 & 0.07995 \\
\hline
\end{tabular}

Cross Loadings

\begin{tabular}{|l|r|r|r|r|}
\hline & \multicolumn{1}{|l|}{ X1 } & \multicolumn{1}{l|}{ X2 } & \multicolumn{1}{l|}{ Y1 } \\
\hline X1.1 & 0.77943 & 0.78446 & 0.76336 & 0.77437 \\
\hline X1.2 & 0.95033 & 0.92053 & 0.93673 & 0.93812 \\
\hline X2.1 & 0.95882 & 0.96401 & 0.95589 & 0.96971 \\
\hline X2.2 & 0.85806 & 0.95853 & 0.83157 & 0.88967 \\
\hline Y1.1 & 0.95237 & 0.87574 & 0.96208 & 0.93351 \\
\hline Y1.2 & 0.96414 & 0.92477 & 0.97517 & 0.94909 \\
\hline Y2.1 & 0.63765 & 0.57527 & 0.69107 & 0.63040 \\
\hline Y2.2 & 0.93315 & 0.93946 & 0.91146 & 0.95573 \\
\hline Y2.3 & 0.96570 & 0.95089 & 0.95087 & 0.98136 \\
\hline
\end{tabular}

\section{Latent Variable Correlations}

\begin{tabular}{|l|r|r|r|r|}
\hline & \multicolumn{1}{|l|}{ X1 } & \multicolumn{1}{|l|}{ X2 } & Y2 \\
\hline $\mathrm{X} 1$ & 1 & & & \\
\hline $\mathrm{X} 2$ & 0.94781 & 1 & & \\
\hline $\mathrm{Y} 1$ & 0.98917 & 0.93319 & 1 & \\
\hline $\mathrm{Y} 2$ & 0.98366 & 0.96931 & 0.97209 & 1 \\
\hline
\end{tabular}

